\author{
Nikola BYRTEK ${ }^{1}$, Grzegorz BIESOK ${ }^{2}$ \\ Opiekun naukowy: Grzegorz BIESOK ${ }^{2}$ \\ DOI: https://doi.org/10.53052/9788366249844.04
}

\title{
FUNKCJONOWANIE SYSTEMÓW LOGISTYCZNYCH W OPINII PRACOWNIKÓW PRZEDSIĘBIORSTW
}

\begin{abstract}
Streszczenie: Publikacja przedstawia wyniki badań ankietowych prowadzonych wśród pracowników przedsiębiorstw województwa Śląskiego, a dotyczących subiektywnej oceny funkcjonowania systemów logistycznych. Badania pokazały, iż respondenci są świadomi znaczenia systemu logistycznego w efektywnym funkcjonowaniu przedsiębiorstwa, jak również dostrzegają wzajemnie powiązania między podsystemami logistycznymi. Za najważniejsze obszary logistyki uważają obsługę zamówień i logistykę produkcji.
\end{abstract}

Słowa kluczowe: logistyka, systemy logistyczne przedsiębiorstw

\section{FUNCTIONING OF LOGISTIC SYSTEMS IN THE OPINION OF EMPLOYEES OF ENTERPRISES}

Summary: The paper presents the results of surveys conducted among employees of enterprises in the Sląskie Voivodeship, concerning the subjective assessment of the functioning of logistics systems. The research showed that the respondents are aware of the importance of the logistics system in the effective functioning enterprise, as well as perceive the interrelationships between the logistics subsystems. They consider order handling and production logistics to be the most important areas of logistics.

Keywords: logistics, logistics systems

\section{Systemy i podsystemy logistyczne}

Współczesną logistykę charakteryzuje równoczesne uwzględnianie działań strategicznych i operacyjnych. Działaniom tym przyświecają fundamentalne zasady logistyki, takie jak [1]:

- celowość - mająca zapewnić optymalne warunki funkcjonowania firmom, przy jednoczesnym osiąganiu maksymalnych wyników ekonomicznych,

1 Akademia Techniczno-Humanistyczna w Bielsku-Białej, Wydział Zarządzania i Transportu, kierunek zarządzanie, spec. zarządzanie logistyką i jakością, email: nikola.tobiasz@gmail.com 2 dr inż., Akademia Techniczno-Humanistyczna w Bielsku-Białej, Wydział Zarządzania i Transportu, email: gbiesok@ath.eu 
- efektywność - każde działanie podejmowane przez przedsiębiorstwo powinno prowadzić do najwyższej efektywności ekonomicznej,

- kompleksowość - dzięki której wszelkie procesy logistyczne są ściśle związane z innymi dziedzinami funkcjonowania przedsiębiorstwa.

Nadrzędnymi celami działań logistycznych są [2]:

- koordynacja przepływu surowców, materiałów do produkcji i wyrobów gotowych do konsumentów oraz związanych z nimi informacji,

- optymalizacja przepływu, eliminacja wąskich gardeł i zbędnych ogniw pośrednich,

- zmniejszenie zapasów,

- minimalizacja kosztów przepływu,

- skrócenie czasu przepływu, czasu realizacji dostaw

- zapewnienie właściwego poziomu obsługi klienta.

Z logistyką nieodłącznie związane są struktury zwane systemami logistycznymi. System logistyczny można ująć jako układ wzajemnie powiązanych elementów, w którym odbywają się procesy przestrzenno-czasowej transformacji dóbr. Zdaniem Topolskiej i Topolskiego, system logistyczny funkcjonuje w trzech płaszczyznach (strukturach) [3]:

- $\quad$ przestrzennej (łączy elementy systemu i przepływ strumieni),

- organizacyjnej (organizuje elementy systemu),

- informacyjnej (przejawia się w przepływie strumieni finansowych $\mathrm{i}$ informacji).

Podstawą organizacji i struktury systemów logistycznych jest ogólna teoria systemów. System jest to ogólna całość, w której każdy z elementów jest wzajemnie powiązany ze sobą. Za system uznawany jest również skoordynowany wewnętrznie i posiadający określoną strukturę układu elementów zespół procedur, sposobów czy metod. [4]. Pojęcie systemu obejmuje także całokształt zasad organizacyjnych oraz ogół reguł, norm obowiązujący w danej dziedzinie [5].

Wszystkie elementy systemu istnieją po to, aby realizować główny cel całości. System składa się z wielu mniejszych elementów dalej zwanymi podsystemami. Elementy te to oddzielne systemy powiązane ze sobą licznymi zależnościami, w sposób taki, aby każdy realizował czy wspierał założone cele organizacji [6]

Podsystemy logistyczne można podzielić ze względu na fazy przepływu dóbr (podejście fazowe) lub na funkcje realizowane przez poszczególne podsystemy (podejście funkcjonalne). W podejściu fazowym można wyróżnić następujące rodzaje podsystemów logistycznych:

- $\quad$ Logistyka zaopatrzenia - jest systemem ściśle związanym z rynkiem. Łączy ona logistykę dystrybucji dostawców z logistyką produkcji w przedsiębiorstwie. Ma ona zapewnić nie tylko fizyczną, ale i prawną dostępność towarów niewytwarzanych bezpośrednio przez przedsiębiorstwo, ale przez nie używanych np. w procesie produkcji [7].

- Logistyka produkcji - zlokalizowana jest pomiędzy logistyką zaopatrzenia a logistyką dystrybucji. Obejmuje każdą czynność związaną z zaopatrzeniem procesu produkcji w potrzebne materiały, półwyroby, części zamienne oraz przekazywaniem półwyrobów bądź produktów gotowych do magazynu zbytu [8]. Bardzo duży wpływ na logistykę produkcji, wywiera ukształtowanie systemu produkcyjnego, ukształtowanie 
Funkcjonowanie systemów logistycznych w opinii pracowników przedsiębiorstw 39

systemu planowania oraz sterowania produkcją. Pomiędzy tymi obszarami istnieją powiązania [7].

- Logistyka dystrybucji - powiązana jest z rynkiem. Łączy logistykę produkcji danego przedsiębiorstwa z logistyką zaopatrzenia nabywcy [9]. Zajmuje się czynnościami związanymi z dostarczaniem do klientów towarów gotowych (także półproduktów i itp.).

- Logistyka części zamiennych - zapewnia nabywcy lub użytkownikowi dostęp do części zamiennych gwarantujący szybką i niezawodną obsługę techniczną, konserwację oraz naprawę zepsutych urządzeń.

- Logistyka powtórnego zagospodarowania (logistyka utylizacji, logistyka zwrotna), zapewniająca przepływ pozostałości, takich jak surowce wtórne, towary uszkodzone, zwroty, opakowania zwrotne, używane pojemniki i opakowania, odpady [10].

W podziale funkcjonalnym można wyróżnić następujące podsystemy:

- Opracowywania zamówień - to wszelkie działania związane z komunikacją klient-sprzedający [11]. Zamówienia są podstawą przepływu wszelakich informacji w systemach logistycznych.

- Gospodarki magazynowej (zarządzania zapasami) i magazynowania - ich rolą jest utrzymanie zapasów magazynowych i kompresowanie różnice pomiędzy popytem a podażą.

- Pakowania (logistyki opakowań) - gdzie zasadniczym celem jest ochrona jakości wyrobu, ale także wsparcie takich procesów, jak transport, magazynowanie, ochrona środowiska, ale także sama rola informacyjna.

- Transportu - który zapewnia przepływ towarów pomiędzy zainteresowanymi stronami, spaja nabywcę ze sprzedającym, tworzy użyteczność nie tylko czasu, ale i miejsca w wyniku fizycznego przemieszczenia towaru w wyznaczonym miejscu i określonym czasie [12].

Sprawność funkcjonowania podsystemów logistycznych w przedsiębiorstwie podlega badaniom i ocenie. Zdaniem M. Kubańskiego, ocena funkcjonowania systemu logistycznego w przedsiębiorstwach powinna składać się z dwóch typów ocen cząstkowych [13]:

- oceny subiektywnej — dotyczącej bezpośrednich uczestników systemu logistycznego (pracowników),

- oceny obiektywnej w oparciu o wskaźniki pomiaru efektywności systemu.

Wg tego autora odpowiednim narzędziem do oceny subiektywnej są badania ankietowe prowadzone wśród uczestników systemu logistycznego [13].

\section{Ocena funkcjonowania podsystemów logistycznych w świetle badań własnych}

\subsection{Charakterystyka przeprowadzonych badań i badanej zbiorowości}

Wykorzystując badania ankietowe, jako sugerowane w literaturze narzędzie subiektywnej oceny funkcjonowania systemów logistycznych, przeprowadzono badanie ankietowe wśród pracowników przedsiębiorstw handlowo-produkcyjnousługowych, prowadzących swoją działalność na terenie województwa śląskiego. Celem badania było poznanie opinii respondentów na temat systemu logistycznego 
oraz efektywności jego funkcjonowania w ich miejscu pracy. Pełne wyniki badań zostały opublikowane w pracy [14].

W badaniach wzięło udział 43 pracowników. Badaną grupę stanowili w większości pracownicy $\mathrm{z}$ dłuższym stażem, zatrudnieni na stanowiskach o charakterze wykonawczym. Wywodzili się oni z różnej wielkości przedsiębiorstw (rys. 1).

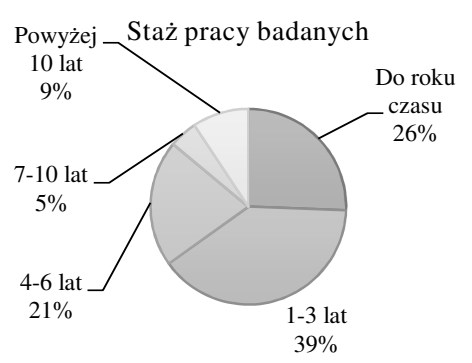

Charakter wykonywanej pracy

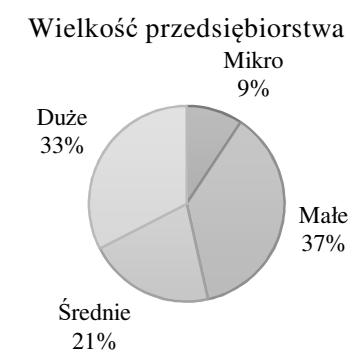

Rysunek 1. Charakterystyka pracowników bioracych udziat w badaniu

Źródto: opracowanie własne

Największa część osób ankietowanych (33\%) odpowiedziała, że obszarem logistycznym dotyczącym bezpośrednio ich stanowiska pracy jest opracowanie zamówień, 26\% respondentów pracuje w obszarze logistycznym logistyki produkcji. Kolejno 16\% osób pracuje w obszarze logistyki zaopatrzenia. Pozostałe obszary logistyki dotyczyły mniejszej ilości respondentów (rys. 2).

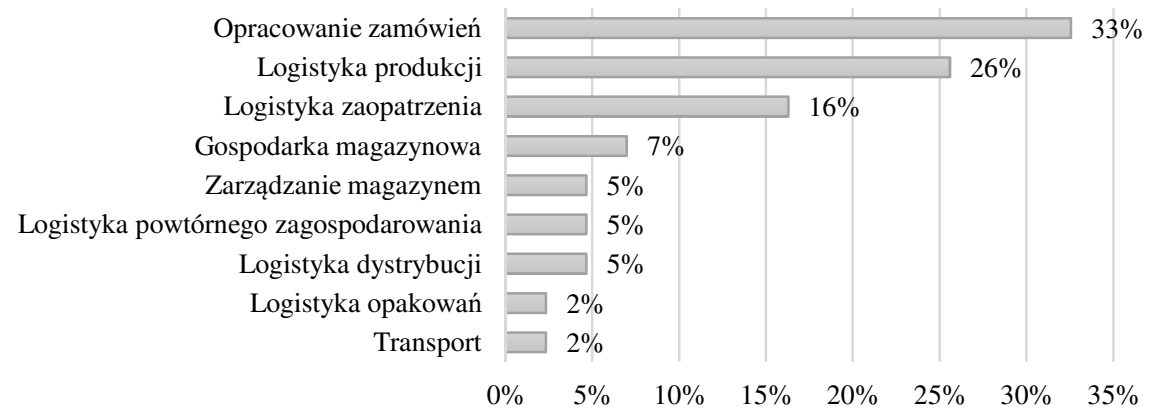

Rysunek 2. Obszary logistyczne bezpośrednio dotyczące badanych

Źródto: opracowanie własne. 


\subsection{Funkcjonowanie systemów logistycznych przedsiębiorstw w opinii badanych}

Znaczna część badanych zadeklarowała w swoich przedsiębiorstwach istnienie funkcjonalnego podejścia do logistyki (65\%), a więc skupienie się głównie, na takich obszarach jak: obsługa zamówień, gospodarka magazynowa, magazyn, opakowania, transport. Natomiast $35 \%$ pracowników pracuje w przedsiębiorstwach, które charakteryzują się podejściem fazowym, które wyróżnia takie elementy, jak: logistyka zaopatrzenia, logistyka produkcji, logistyka dystrybucji, logistyka części zamiennych oraz logistyka powtórnego zagospodarowania (rys. 3).

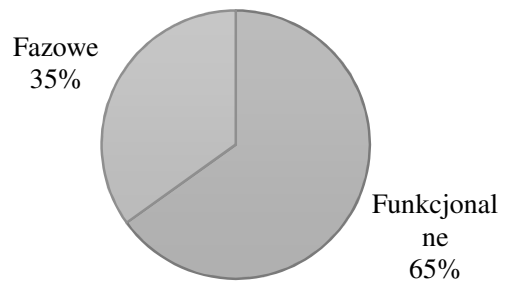

Rysunek 3. Podejścia do logistyki w badanych przedsiębiorstwach

Źródto: opracowanie własne

Zdecydowana większość badanych uważa, że system logistyczny w znacznym stopniu wpływa na efektywne funkcjonowanie przedsiębiorstwa - aż 49\% uczestników badania zdecydowanie zgadza się z tym twierdzeniem, a 35\% raczej zgadza się. Mają oni zatem świadomość znaczenia systemów logistycznych w swoich przedsiębiorstwach

Czy zgadza się Pan/ Pani z twierdzeniem, iż system logistyczny w znacznym stopniu wpływa na efektywne funkcjonowanie przedsiębiorstwa?

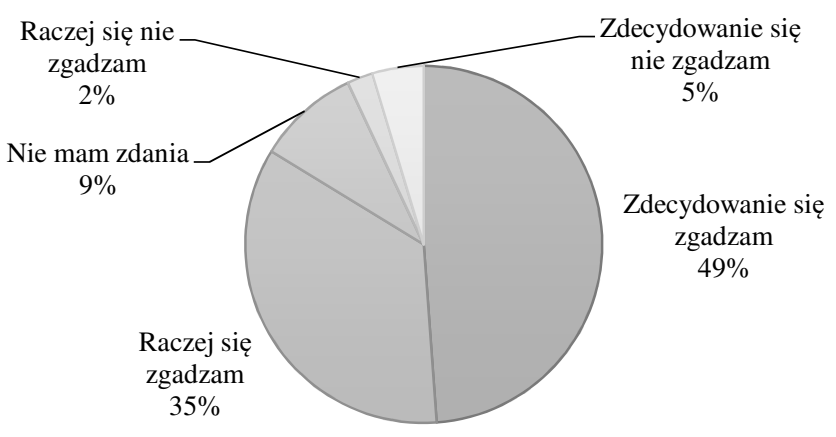

Rysunek 4. System logistyczny a efektywność funkcjonowania przedsiębiorstwa

Źródto: opracowanie własne

Co ciekawe - bardziej ostrożni w tych osądach są przedstawiciele kadry kierowniczej (rys 5). 


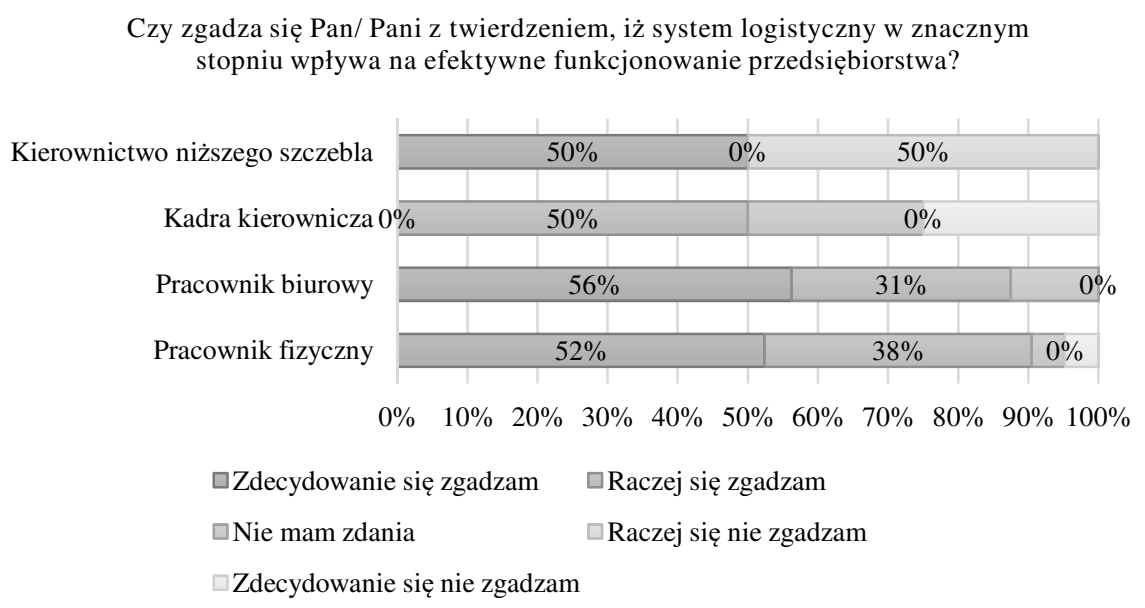

Rysunek 5. Ocena wptywu systemu logistycznego na efektywność przedsiębiorstwa w odniesieniu do stanowiska pracy badanych

\section{Źródto: opracowanie wtasne}

Znaczna część respondentów (47\%) zdecydowanie zgodziła się z twierdzeniem, iż każdy z podsystemów logistycznych oddziałuje wzajemnie na inne. Aż $30 \%$ badanych raczej zgodziło się z powyższym twierdzeniem, $19 \%$ respondentów nie posiadało zdania na ten temat, $2 \%$ przebadanych raczej się nie zgodziło $\mathrm{z}$ owym twierdzeniem, a $2 \%$ zdecydowanie nie zgodziło się $\mathrm{z}$ twierdzeniem. Zdecydowana większość ankietowanych pracowników widzi zależności pomiędzy podsystemami logistycznymi przedsiębiorstwa. Badani wydają się być świadomi, że każdy błąd w pracy jednego podsystemu może mieć negatywny wpływ na działanie innego.

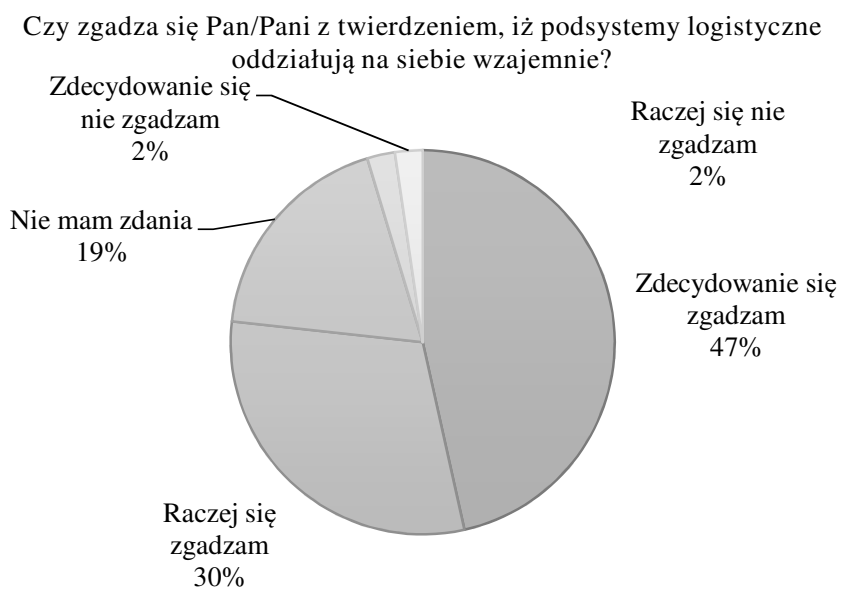

Rysunek 6. Wzajemne oddziatywanie podsystemów logistycznych w opinii badanych

Źródto: opracowanie wtasne 
Respondenci, zapytani o ocenę ważności poszczególnych podsystemów w przedsiębiorstwie, stwierdzili, iż najważniejszym podsystemem logistycznym jest opracowanie zamówień, a najmniej ważnym - logistyka części zamiennych. Jednak, różnice w ocenie ważności wielu podsystemów nie są zbyt wielkie (rys. 7).

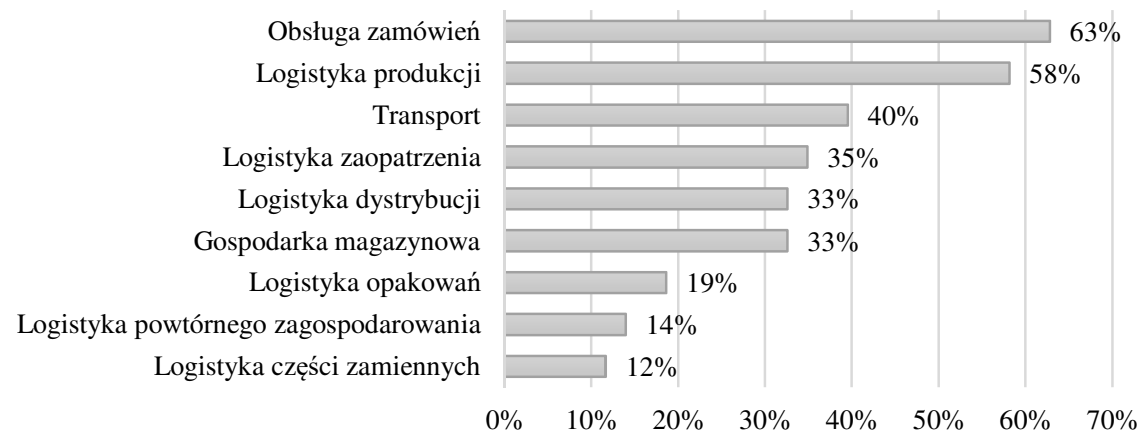

Rysunek 7. Ważność podsystemów logistycznych w opinii badanych

Źródło: opracowanie własne. Można było wskazać kilka podsystemów, stąd frakcje nie sumuja się do $100 \%$.

Respondenci zauważyli także, że pomiędzy podsystemami zachodzą ścisłe powiązania. Najsilniejsze relacje badani wskazali między podsystemami obsługi zamówień, zarządzania zapasami i zarządzania magazynem.

\section{Podsumowanie}

System logistyczny jest bardzo ważnym elementem w efektywnym funkcjonowaniu przedsiębiorstwa. W jego skład wchodzi wiele elementów, utrzymujących prawidłowe funkcjonowanie przedsiębiorstwa. Każdy z tych elementów powinien być zintegrowany z pozostałymi i wciąż doskonalony dla utrzymania efektywności całego systemu.

Badania ankietowe pokazały, iż pracownicy przedsiębiorstw są świadomi znaczenia systemu logistycznego w efektywnym funkcjonowaniu przedsiębiorstwa, jak również dostrzegają wzajemnie powiązania między podsystemami logistycznymi. Opinia ta wydaje się być bardziej ugruntowana wśród pracowników operacyjnych: produkcyjnych lub biurowych, być może dlatego, że są oni najbliżej związani $\mathrm{z}$ procesami zachodzącymi w firmie i w pierwszej kolejności narażeni są na problemy wynikające $\mathrm{z}$ niesprawności systemu logistycznego. Bardziej wyważona postawa kierownictwa może wynikać $\mathrm{z}$ faktu, że nie zawsze ma ono pełną wiedzę na temat problemów występujących w organizacji.

W opinii badanych, najważniejszymi obszarami logistyki jest obsługa zamówień i logistyka produkcji, ale może to wynikać z przeświadczenia respondentów, że obszar, w którym sami pracują, pełni bardziej istotną rolę w funkcjonowaniu całości przedsiębiorstwa. 
Reasumując, pozytywnym obrazem wyłaniającym się z badań, jest świadomość znaczenia i systemowości działań logistycznych przedsiębiorstwa. Taka postawa jest właściwą podbudową do optymalizacji procesów logistycznych wewnątrz organizacji, bez uciekania się do innych podejść, jak choćby outsourcingu logistycznego - por. [15].

\section{LITERATURA}

1. BLAIK P., Logistyka, Wydawnictwo PWE, Warszawa, 2001.

2. BIESOK G. (red.), Logistyka usług, CeDeWu, Warszawa, 2013.

3. TOPOLSKA K., TOPOLSKI M., System logistyczny przedsiębiorstwa i jego struktura przestrzenna, Logistics and Transport, 3 (2006), 67-73.

4. SZCZEPAŃSKA K., Zarządzanie jakością w dążeniu do doskonałości, Wydawnictwo CH. Beck, Warszawa, 2010.

5. BUJAK A., KŁOSOWSKI, J., System logistyczny przedsiębiorstwa i jego parametry, Logistyka, 3 (2014), 882-890.

6. SŁOWIŃSKI B., Wprowadzenie do logistyki, Wydawnictwo Uczelniane Politechniki Koszalińskiej, Koszalin, 2008.

7. PFOHL, H. CH. Systemy logistyczne, podstawy organizacji i zarządzania, Instytut Logistyki i Magazynowania, Poznań, 1999.

8. MATULEWSKI M., KONECKA S., FAJFER P., WOJCIECHOWSKI A., Systemy logistyczne, Instytut Logistyki i Magazynowania, Poznań, 2008.

9. PISZ I., SĘK T., ZIELECKI W., Logistyka w przedsiębiorstwie, Polskie Wydawnictwo Ekonomiczne, Warszawa, 2013.

10. FERTSCH M., Podstawy logistyki, Instytut Logistyki i Magazynowania, Poznań, 2008.

11. NOWICKA-SKOWRON M., Efektywność systemów logistycznych, PWE, Warszawa, 2000.

12. COYLE J. J., BARDI E. J., LANGLY JR. C., Zarządzanie logistyczne, Wydawnictwo PWE, Warszawa, 2002.

13. KUBAŃSKI M., Systemy logistyczne, Wydawnictwo Naukowe Akademii Techniczno-Humanistycznej w Bielsku-Białej, Bielsko-Biała, 2015.

14. TOBIASZ N., Rola systemu logistycznego w efektywnym funkcjonowaniu przedsiębiorstwa (praca dyplomowa licencjacka), Akademia TechnicznoHumanistyczna w Bielsku-Białej, Bielsko-Biała, 2020.

15. WYRÓD-WRÓBEL J., Outsourcing jako kompleksowa realizacja usług logistycznych, w: R. Barcik i in. (red.), Logistyka: perspektywy u progu Wspólnej Europy, Wydawnictwo Akademii Techniczno-Humanistycznej w Bielsku-Białej, Bielsko-Biała, 2004, 121-127. 